\title{
Species Counterpoint: Pendekatan Dalam Pembelajaran Kontrapung
}

\author{
Oriana Tio Parahita Nainggolan', Ovan Bagus Jatmika² \\ ${ }^{12}$ Program Studi S-1 Pendidikan Musik, Fakultas Seni Pertunjukan, \\ Institut Seni Indonesia Yogyakarta \\ Email: orianatioparahitangl@gmail.com
}

\begin{abstract}
As a part of music theory, Counterpoint dealing with a combination of melody in contrary motion. It is focused on combining melody between cantus firmus and counterpoint. In learning counterpoint, there are two approaches which usually used, free Counterpoint and strict counterpoint (it is well known as species counterpoint). The free counterpoint method allows writing counterpoint melody without paying attention to Counterpoint rules. While in strict counterpoint does not give freedom to write counterpoint melody, hence in must follow Counterpoint rules. Based on an early observation of this study, it found that the free counterpoint method did not give a strong understanding of basic counterpoint to the students. It is showed that students are confused when they made a Counterpoint melody. They stated that they were confused about how to start the melodies and also how to develop their melody because they don't have a strong basis of counterpoint rules. This research aims to analyze the role of species counterpoint in giving a rudiment to the students. Species counterpoint used here as a pedagogical tool, which makes students learned through several steps called species. This is qualitative research. The data acquired from observation and interviews during learning Counterpoint at Music Education Study Program, Faculty of Performing Arts, Institut Seni Indonesia Yogyakarta. The results showed that species counterpoint builds a strong fundamental theory in writing counterpoint melody. Moreover, it also helps students to increase their skills in writing a counterpoint melody.
\end{abstract}

Keywords: Counterpoint; Cantus Firmus; Species Counterpoint; Melody.

Abstrak: Kontrapung merupakan cabang dari Teori Musik untuk menyusun kombinasi melodi secara berlawanan antara cantus firmus dan counterpoint. Dalam pembelajaran Kontrapung terdapat dua pendekatan yaitu free counterpoint dan strict counterpoint (species counterpoint). Free counterpoint memberikan kebebasan dalam membuat melodi Kontrapung, sementara strict counterpoint harus mempertimbangkan berbagai macam kaidah dalam membuat melodi Kontrapung. Berdasarkan observasi awal, penggunaan free counterpoint dalam pembelajaran Kontrapung tidak memberikan dasar yang kuat untuk dapat membuat melodi Kontrapung. Untuk mengatasi hal tersebut, maka sebaiknya pembelajaran Kontrapung dilakukan dengan menggunakan pendekatan species counterpoint. Penelitian ini bertujuan untuk mendeskripsikan penggunaan species counterpoint pada pembelajaran Kontrapung dalam membuat melodi Kontrapung. Penelitian ini merupakan penelitian kualitatif deskriptif. Data penelitian didapat dari hasil observasi dan wawancara yang dilakukan selama pembelajaran Kontrapung di Program Studi S-1 Pendidikan Musik, Fakultas Seni Pertunjukan, Institut Seni Indonesia Yogyakarta. Hasil penelitian menunjukkan bahwa pembelajaran Kontrapung dengan menggunakan pendekatan species counterpoint dapat meningkatkan pemahaman terhadap kaidah-kaidah Kontrapung dalam membuat melodi Kontrapung, selain itu pembelajaran Kontrapung dengan species counterpoint juga meningkatkan keterampilan dalam membuat melodi Kontrapung.

Kata Kunci: Kontrapung; Cantus Firmus; Species Counterpoint; Melodi.

Article info:

Received: 19 Februari 2021

Reviewed: 04 April 2021

Accepted: 27 Juni 2021

\section{PENDAHULUAN}

Kontrapung atau yang dalam bahasa Inggris disebut counterpoint merupakan seni dalam menyusun melodi (York, 1907).
Kontrapung berasal dari bahasa Latin "Punctus contra punctum" (note against note) atau dalam bahasa Indonesia nada melawan nada (Norden, 1969). Penekanan dari arti kata Kontrapung 
adalah pada kata 'melawan' yang berarti penyusunan melodi secara berlawanan (Artinya terdapat dua atau lebih melodi yang ada pada suara atas dan bawah dan disusun secara berlawanan (Jeppesen \& Haydon, 1935).

Tujuan utama dalam pembelajaran Kontrapung adalah agar dapat membuat melodi Kontrapung yang baik. Untuk dapat membuat melodi Kontrapung yang baik, dibutuhkan pemahaman akan kaidah-kaidah serta latihanlatihan membuat melodi Kontrapung. Namun hal pertama yang harus dikuasai adalah pemahaman akan kaidah-kaidah Kontrapung. Oleh karena itu pembelajaran Kontrapung dilaksanakan dengan memberikan pemahaman akan kaidah-kaidah Kontrapung dan dilanjutkan dengan latihan membuat melodi Kontrapung secara bertahap.

Dalam pembelajaran Kontrapung terdapat dua macam pendekatan yaitu free counterpoint dan strict counterpoint. Free counterpoint memberikan kebebasan dalam pemilihan nada untuk membentuk melodi Kontrapung, sedangkan strict counterpoint akan merujuk pada kaidah-kaidah Kontrapung dalam pembuatan melodi Kontrapung. Pembelajaran Kontrapung dengan menggunakan pendekatan free counterpoint memang memberikan kebebasan dalam membuat melodi Kontrapung, namun pendekatan ini kurang memberikan dasar pemahaman akan kaidah Kontrapung yang kuat. Hal ini diketahui dari hasil observasi dan wawancara yang dilakukan pada mahasiswa Program Studi (Prodi) S-1 Pendidikan Musik, Fakultas Seni Pertunjukan, Institut Seni Indonesia Yogyakarta yang menempuh perkuliahan Kontrapung di semester genap Tahun Akademik 2019/2020. Dari 38 mahasiswa, sekitar $65 \%$ atau sekitar 25 orang menyatakan bahwa dengan metode free counterpoint, mereka mendapat kebebasan membuat melodi kontrapung tetapi tidak paham akan detail aturan kontrapung.

Pembelajaran Kontrapung dengan menggunakan pendekatan strict counterpoint atau yang sering disebut species counterpoint (Komosinski \& Szachewicz, 2015) memberikan pemahaman yang kuat akan kaidah Kontrapung, karena dilakukan dengan secara bertahap. Tahapan tersebut biasa disebut species. Species counterpoint merupakan pendekatan pedagogis yang digunakan untuk meningkatkan pemahaman terhadap kaidah Kontrapung yang pada akhirnya dapat meningkatkan kemampuan membuat melodi kontrapung (Fux \& Wollenberg, 1992). Penelitian ini dilakukan untuk mendeskripsikan penggunaan pendekatan species counterpoint pada pembelajaran Kontrapung di Prodi S-1 Pendidikan Musik, Fakultas Seni Pertunjukan, Institut Seni Indonesia Yogyakarta dalam memahami kaidah penyusunan melodi kontrapung. Pendekatan ini dipilih karena pendekatan free counterpoint kurang memberikan pemahaman tentang kaidah penyusunan melodi kontrapung. Hasil penelitian ini diharapkan dapat menjadi solusi dalam meningkatkan pemahaman mahasiswa Prodi S-1 Pendidikan Musik, Fakultas Seni Pertunjukan, Insitut Seni Indonesia Yogyakarta, terhadap penyusunan melodi kontrapung pada mata kuliah Kontrapung.

\section{METODE}

Penelitian ini dilakukan di Prodi S-1 Pendidikan Musik, Fakultas Seni Pertunjukan, Institut Seni Indonesia Yogyakarta pada semester genap Tahun Akademik 2019/2020. Metode penelitian yang digunakan pada penelitian ini adalah kualitatif-deskriptif. Metode ini dipilih karena pada penelitian ini akan mendeskripsikan pembelajaran Kontrapung dengan menggunakan pendekatan species counterpoint. Subjek penelitian ini adalah 38 mahasiswa Prodi S-1 Pendidikan Musik yang mengikuti perkuliahan Kontrapung pada semester genap Tahun Akademik 2019/2020. Data penelitian diambil berdasarkan simpulan dan analisis dari hasil observasi dan wawancara. Analisis data penelitian dilakukan dengan menggunakan tahapan analisis data Milles dan Huberman yang terdiri dari reduksi data, penyajian data, dan penarikan kesimpulan serta verifikasi (Sugiyono, 2013).

\section{HASIL DAN PEMBAHASAN}

Pembelajaran Kontrapung dengan menggunakan pendekatan species counterpoint di Prodi S-1 Pendidikan Musik, Fakultas Seni Pertunjukan, Institut Seni Indonesia Yogyakarta dilakukan setelah ditemukan fakta bahwa hampir sebagian besar mahasiswa kurang paham terhadap kaidah penyusunan melodi kontrapung dengan menggunakan pendekatan free counterpoint, sehingga digunakan pendekatan species counterpoint. Implementasi pembelajaran Kontrapung dengan menggunakan species counterpoint dilakukan selama 10 kali pertemuan. Pembelajaran dilakukan dengan terlebih dahulu menyampaikan kaidah penyusunan melodi kontrapung pada masing-masing species dan 
dilanjutkan dengan latihan membuat melodi kontrapung.

Hasil pembelajaran Kontrapung di Prodi S1 Pendidikan Musik, Fakultas Seni Pertunjukan, Institut Seni Indonesia Yogyakrta, dengan menggunakan pendekatan species counterpoint adalah meningkatnya pemahaman mahasiswa terhadap kaidah penyusunan melodi kontrapung. Hasil ini didapat dari nilai yang diperoleh mahasiswa pada akhir pembelajaran Kontrapung setelah menggunakan pendekatan species counterpoint. Nilai yang didapat pada akhir pembelajaran Kontrapung dengan menggunakan species counterpoint kemudian dibandingkan dengan nilai yang didapat mahasiswa pada pembelajaran Kontrapung awal dengan menggunakan pendekatan free counterpoint. Nilai yang menjadi indikator keberhasilan pembelajaran Kontrpung adalah nilai sangat baik (A) dan nilai baik (B). Berikut adalah nilai hasil belajar mahasiswa selama pembelajaran Kontrapung:

Tabel 1. Nilai Hasil Belajar Mahasiswa Dengan Menggunakan Pendekatan Free Counterpoint

\begin{tabular}{cclcc}
\hline No & Nilai & Huruf & $\begin{array}{c}\text { Jumlah } \\
\text { Maha- } \\
\text { siswa }\end{array}$ & Persentase \\
\hline 1 & $91-100$ & A (Sangat Baik) & 3 & $8 \%$ \\
2 & $75-90$ & B (Baik) & 12 & $32 \%$ \\
3 & $60-74$ & Cukup (C) & 18 & $47 \%$ \\
4 & $50-59$ & Kurang (D) & 5 & $13 \%$ \\
& & Jumlah & $\mathbf{3 8}$ & $\mathbf{1 0 0 \%}$ \\
\hline
\end{tabular}

Tabel 2. Nilai Hasil Belajar Mahasiswa Dengan Menggunakan Pendekatan Species Counterpoint

\begin{tabular}{ccccc}
\hline No & Nilai & Huruf & $\begin{array}{c}\text { Jumlah } \\
\text { Maha- } \\
\text { siswa }\end{array}$ & Persentase \\
\hline 1 & $91-100$ & A (Sangat Baik) & 10 & $26 \%$ \\
2 & $75-90$ & B (Baik) & 22 & $58 \%$ \\
3 & $60-74$ & Cukup (C) & 4 & $11 \%$ \\
4 & $50-59$ & Kurang (D) & 2 & $5 \%$ \\
& & Jumlah & $\mathbf{3 8}$ & $\mathbf{1 0 0 \%}$ \\
\hline
\end{tabular}

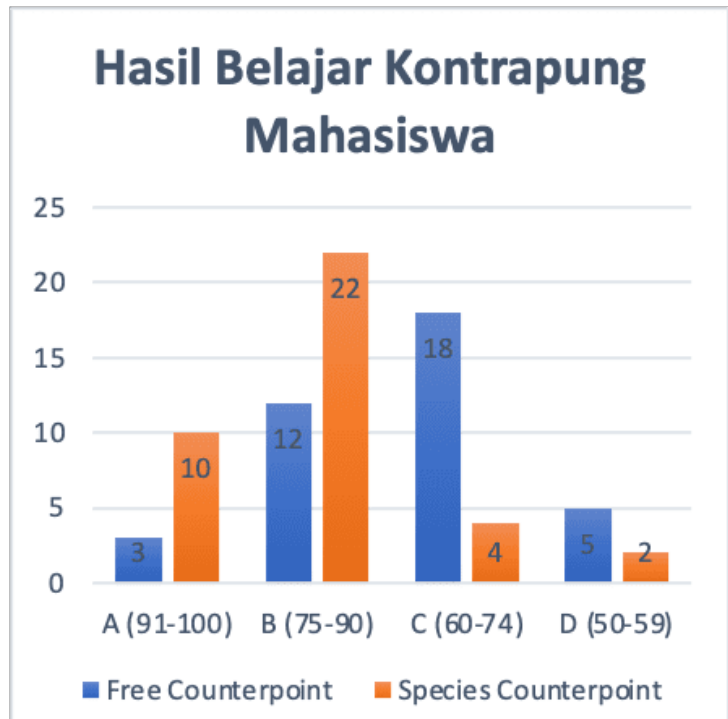

Gambar 1. Diagram Hasil Belajar Kontrapung Mahasiswa
Berdasarkan tabel nilai hasil belajar mahasiswa dengan menggunakan free counterpoint dan species counterpoint di atas diketahui terjadi peningkatan jumlah mahasiswa yang mendapat nilai sangat baik dan baik. Dari data tersebut diketahui bahwa pada pembelajaran Kontrapung dengan pendekatan free counterpoint jumlah mahasiswa yang mendapat nilai sangat baik dan baik sebanyak 15 orang (40\% dari 38 mahasiswa), sedangkan jumlah mahasiswa yang mendapat nilai sangat baik dan baik pada pembelajaran Kontrapung dengan pendekatan species counterpoint sebanyak 32 orang $(85 \%$ dari 38 mahasiswa). Dari data nilai hasil belajar mahasiswa tersebut disimpulkan bahwa terjadi peningkatan jumlah mahasiswa yang mendapat nilai sangat baik dan baik sebanyak $45 \%$.

Data hasil belajar mahasiswa tidak saja menunjukkan peningkatan jumlah mahasiswa yang memperoleh nilai sangat baik dan baik, tetapi 
juga menunjukkan peningkatan pemahaman mahasiswa terhadap kaidah penyusunan melodi kontrapung pada pembelajaran Kontrapung. Pemahaman mahasiswa akan penyusunan melodi Kontrapung menjadikan mahasiswa lebih terampil dalam menyusun melodi kontrapung. Hasil ini didukung data dari hasil wawancara terhadap mahasiswa pada akhir pembelajaran yang hampir sebagian besar menyatakan bahwa pembelajaran Kontrapung dengan menggunakan pendekatan species counterpoint membuat mereka menjadi lebih paham tentang penggunaan interval dalam membentuk melodi kontrapung, aturan pergerakan nada, penggunaan nada suspensi dan tied note, larangan-larangan seperti paralel oktaf dan kwin yang tidak diperbolehkan digunakan dalam penyusunan melodi kontrapung, serta kaidahkaidah lainnya yang membantu mahasiswa membuat melodi kontrapung yang tidak saja benar secara kaidah kontrapung, tetapi juga memiliki nilai estetika musikal yang baik.

\section{Pembelajaran}

Pembelajaran Kontrapung di Prodi S-1 Pendidikan Musik, Fakultas Seni Pertunjukan, Institut Seni Indonesia Yogyakarta merupakan proses interaksi yang melibatkan peserta didik, pendidik, dan sumber belajar dalam sebuah lingkungan belajar (Hanafy, 2014). Interaksi yang terjadi antara peserta didik dan pendidik memungkinkan pembelajaran berjalan dengan efektif, artinya pendidik akan mengetahui dan memahami apabila terjadi permasalahan pada pembelajaran yang sedang berjalan. Pembelajaran yang efektif adalah pembelajaran yang memberikan kemudahan pada peserta didik (Sastrawan, 2016). Interaksi pendidik dan peserta didik memungkinkan pendidik untuk merancang strategi pembelajaran yang sesuai dengan situasi belajar peserta didik guna memberikan kemudahan kepada peserta didik.

Memberikan kemudahan kepada peserta didik merupakan sebuah upaya membantu peserta didik. Menurut Pane dan Dasapong, tujuan pembelajaran adalah membantu peserta didik (Pane \& Dasopang, 2017) untuk memperoleh pengalaman, dan melalui pengalaman tersebut perilaku peserta didik akan berubah (Falahudin, 2014). Perubahan perilaku peserta didik meliputi: pengetahuan, keterampilan, serta nilai atau norma yang berfungsi sebagai pengendali sikap dan perilaku peserta didik. Perubahan tingkah laku peserta didik dapat diketahui melalui nilai hasil belajar peserta didik, yaitu dengan melihat jumlah peserta didik yang mendapat nilai sangat baik dan baik. Semakin banyak peserta didik yang mendapat nilai sangat baik dan baik, maka akan semakin baik pula kualitas pembelajaran yang dilakukan, karena terjadi perubahan perilaku peserta didik. Perubahan perilaku peserta didik terjadi ketika peserta didik telah memiliki pengetahuan dan keterampilan yang didapat dari pembelajaran.

Pembelajaran yang efektif tidak saja memberikan kemudahan pada peserta didik, tetapi juga memberikan kemudahan pada pendidik. Kemudahan dalam mengajar peserta didik didapat pendidik dari proses trial and error selama proses pembelajaran. Proses trial and error memungkinkan terjadinya pengembangan metode pembelajaran sehingga dapat mengoptimalkan proses pembelajaran (Atmadja, 2009). Proses pembelajaran yang optimal akan membuat proses pembelajaran mencapai tujuan pembelajaran yang dirancang. Menurut Darsono, tujuan pembelajaran dapat dicapai apabila: (a) Pembelajaran dilakukan secara sadar dan sistematis; (b) Pembelajaran menumbuhkan perhatian dan motivasi siswa dalam belajar; (c) Pembelajaran dapat membuat siswa siap menerima pelajaran baik secara fisik maupun psikologis; (d) Pembelajaran dapat menyediakan bahan ajar yang menarik dan menantang bagi siswa; (e) Pembelajaran dapat menggunakan alat bantu belajar yang tepat dan menarik; dan (f) Pembelajaran dapat menciptakan suasana belajar yang aman dan menyenangkan bagi siswa (Darsono, 2000).

Apabila tujuan pembelajaran dapat terpenuhi, maka pembelajaran akan disebut sebagai pembelajaran yang berkualitas. Dua unsur yang membentuk pembelajaran berkualitas adalah proses pembelajaran dan hasil pembelajaran (Cholik, 2017). Pembelajaran yang berkualitas juga harus melibatkan peserta didik secara aktif (Setyosari, 2017). Keterlibatan peserta didik dalam pembelajaran dapat dilihat dari keaktifan peserta didik mengerjakan tugas dan latihan yang diberikan. Selain keterlibatan peserta didik, pembelajaran berkualitas juga harus didukung oleh metode dan pendekatan pembelajaran yang digunakan (Laksono, 2019). Metode dan pendekatan pembelajaran yang tepat akan membuat pembelajaran menjadi efektif dan pada akhirnya menjadikan pembelajaran tersebut berkualitas. Pembelajaran Kontrapung dengan 
menggunakan pendekatan species counterpoint yang dilakukan di Prodi S-1 Pendidikan Musik, Fakultas Seni Pertunjukan, Institut Seni Indonesia Yogyakarta, mendorong keaktifan peserta didik, karena setiap pertemuan pembelajaran, pendidik akan memberikan quiz dan latihan kepada mahasiswa sebagai pengayaan belajar mahasiswa, sehingga mahasiswa paham akan materi pembelajaran yang diberikan.

Pengukuran proses pembelajaran dapat dilakukan dengan menganalisis hasil belajar. Hasil belajar merupakan bagian penting dari sebuah pembelajaran. Hasil belajar dapat digunakan sebagai bahan evaluasi proses pembelajaran yang telah berlangsung sekaligus dapat digunakan untuk mengukur keberhasilan pembelajaran. Ada empat klasifikasi keberhasilan proses pembelajaran (Djamarah \& Zain, 2006): (a) Istimewa atau maksimal, apabila materi pembelajaran dapat dikuasai peserta didik; (b) Baik sekali atau optimal, apabila 76 - 99\% materi pembelajaran dikuasai peserta didik; (c) Baik atau minimal, apabila 60 - 75\% materi pembelajaran dikuasai peserta didik; dan (d) Kurang, apabila 60\% materi pembelajaran dikuasai peserta didik. Selain itu, indikator keberhasilan hasil belajar juga dapat ditentukan oleh persentase jumlah mahasiswa yang menguasai materi pembelajaran yaitu apabila $<75 \%$ dari jumlah mahasiswa mendapat nilai sangat baik dan baik.

Berdasarkan nilai hasil belajar mahasiswa yang didapat pada pembelajaran Kontrapung dengan menggunakan species counterpoint ada sebanyak $84 \%$ dari 38 mahasiswa yang mendapat nilai sangat baik dan baik. Persentase $84 \%$ lebih besar dari persentase indikator keberhasilan yang disyaratkan, yaitu sebanyak $75 \%$. Dari hasil persentase ini diketahui bahwa pembelajaran Kontrapung dengan menggunakan species counterpoint disimpulkan dapat memberikan kemudahan kepada peserta didik sehingga peserta didik memahami kaidah penyusunan melodi kontrapung.

\section{Kontrapung}

Kontrapung atau yang dalam bahasa Inggris disebut counterpoint merupakan seni dalam menyusun melodi (York, 1907). Kontrapung merupakan komposisi musik yang di dalamnya mempertentangkan dua atau lebih melodi (Huang, Cooijmans, Roberts, Courville, \& Eck, 2019). Hal ini sesuai dengan asal kata
Kontrapung sendiri yang berasal dari bahasa Latin "Punctum Contra Punctum" yang diartikan dalam bahasa Inggris "Notes against Notes" (Norden, 1969). Dalam musik, Kontrapung merupakan komposisi musik saling berhubungan antara beberapa melodi yang secara harmoni memiliki kebebasan ritme dan countour (Laitz, 2008).

Pembelajaran Kontrapung merupakan salah satu subjek penting dan wajib bagi mahasiswa musik. Hal ini dikarenakan Kontrapung merupakan bagian dari teori musik (Ren, 2016) yang memberikan dasar pemahaman musik. Kontrapung juga merupakan dasar bagi mahasiswa musik untuk membuat komposisi musik, orkestrasi atau mengaransemen musik. Kontrapung memberikan pemahaman tentang melodi dalam musik, maka itu Kontrapung sering disebut juga sebagai ilmu melodi (Nainggolan, 2018). Fokus utama pembelajaran Kontrapung adalah pembuatan melodi Kontrapung dengan kaidahkaidah Kontrapung.

Pembelajaran Kontrapung bagi pemula dipusatkan pada mempelajari kaidah-kaidah Kontrapung guna membentuk melodi Kontrapung yang baik. Setelah memahami kaidah-kaidah tersebut, maka hal berikutnya yang harus dipelajari adalah teknik dasar dan latihan membuat komposisi Kontrapung. Pembuatan komposisi Kontrapung tidak saja membutuhkan pemahaman yang baik akan kaidah Kontrapung tetapi juga membutuhkan keterampilan teknis. Sehingga pembelajaran Kontrapung akan selalu diawali dengan teori dan dilanjutkan dengan latihan-latihan membuat komposisi Kontrapung. Diharapkan dengan latihan-latihan tersebut didapat keterampilan dalam membuat komposisi Kontrapung.

\section{Species Counterpoint}

Species Counterpoint adalah sebuah metode pembelajaran Kontrapung. Bagi sebagian orang metode ini sering dihindari untuk digunakan karena metode ini merupakan strict counterpoint, yaitu dalam pembelajarannya dilakukan berdasarkan kaidah-kaidah yang berlaku untuk pembuatan melodi Kontrapung. Meskipun dihindari, namun metode pembelajaran ini memberikan dasar pengetahuan yang kuat pada pembuatan melodi Kontrapung. Species counterpoint dikembangkan oleh Johann Joseph Fux pada tahun 1725 (Mazzola, Park, \& Thalmann, 2011). 
Pembelajaran Kontrapung dengan menggunakan species counterpoint terdiri lima langkah yang disebut dengan species (Farbood \& Schöner, 2001). Masing-masing species memiliki tingkat kesulitannya masing-masing. Tingkat kesulitan masing-masing species dibuat bertahap, semakin besar speciesnya semakin kompleks tingkat kesulitannya. Hal ini dikarenakan semakin besar speciesnya maka kaidah-kaidah pada species sebelumnya terus digunakan untuk membentuk melodi Kontrapung (Rothgeb, 1975). Pengerjaan species counterpoint yang paling sederhana terdapat dua layer suara yaitu cantus firmus (CF) dan counterpoint (CPT). Dengan metode species counterpoint, peserta didik akan diberi latihan untuk membuat melodi pada layer counterpoint (melodi Kontrapung), sedangkan layer cantus firmus biasanya merupakan melodi yang sudah ditulis terlebih dahulu oleh pengajar.

Dalam species counterpoint, pembelajaran dibagi dalam lima species. Berikut kelima species tersebut:

a. First species (note against note). First species counterpoint berisikan konsep satu nada pada CF melawan satu nada pada CPT. Nilai nada yang digunakan pada CF dan CPT adalah sama. Sebagai awal pembelajaran, maka nilai nada yang digunakan adalah Semibreve. Pada bagian ini interval nada yang digunakan adalah interval 1 (unisono), interval 3, interval 5, interval 8 , dan interval 8 (oktaf). Pergerakan nada yang digunakan adalah similar, oblique, dan contrary. Interval yang digunakan diawal melodi ditentukan berdasarkan letak melodi CF, apabila CF berada pada suara atas maka melodi CPT akan dimulai dengan menggunakan interval unisono atau oktaf, tetapi apabila CF berada pada suara atas, maka CPT bisa dimulai dengan menggunakan interval unisono,5, atau oktaf. Pergerakan crossing dapat digunakan, tetapi overlapping tidak boleh digunakan.

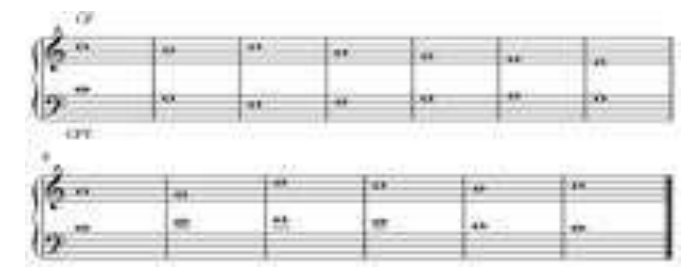

Notasi 1. First Species

b. Second species (two notes against one). Konsep pada bagian ini adalah dua nada pada CPT melawan satu nada pada CF. Dua nada pada CPT memiliki nilai setengah dari nada CF. Pada second species interval nada yang digunakan adalah interval nada yang ada pada species pertama ditambah dengan penggunaan interval nada dissonance (interval 2, interval 4, dan interval 7). Interval dissonance digunakan pada ketukan lemah. Setelah menggunakan interval dissonance, maka harus diselesaikan dengan menggunakan interval consonant. Penggunaan interval dissonance hanya dapat dilakukan dengan pergerakan passing note, dan auxiliary note.

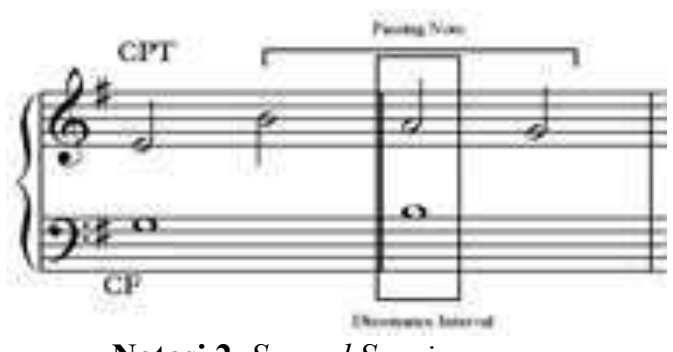

Notasi 2. Second Species

c. Third species (four notes against one). Konsep pada bagian ini adalah empat nada pada CPT melawan satu nada pada CF. Kaidah yang digunakan pada third species ini sama seperti pada kaidah yang ada pada second species. Nada pada ketukan yang kuat biasanya menggunakan interval consonant, sedangkan nada pada ketukan lemah menggunakan interval dissonance. Interval dissonance dapat digunakan dengan menggunakan nota cambiata, changing note, dan descending four note scalewise passage. 


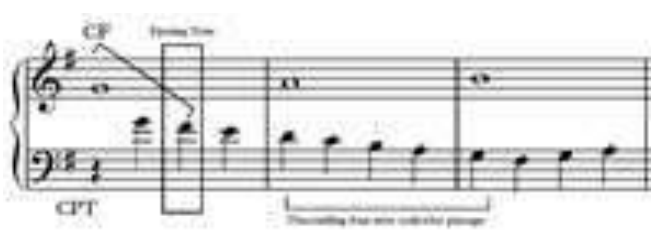

Notasi 3. Third Species

d. $\quad$ Fourth species (two notes against one). Kaidah yang digunakan di sini juga hampir mirip seperti pada kaidah pada species sebelumnya, namun pada bagian ini ditambah dengan penggunaan not syncope dalam bentuk suspension dan tied note yang digunakan melewati garis birama.

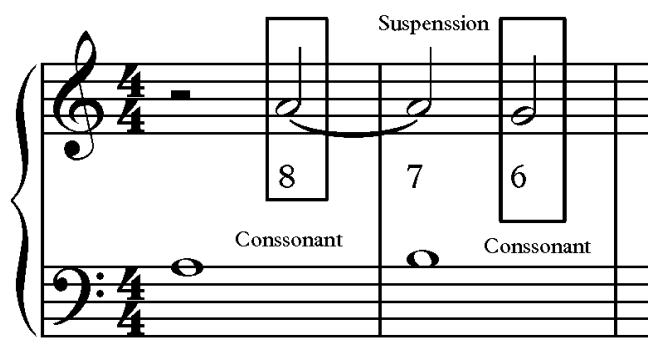

Notasi 4. Suspension

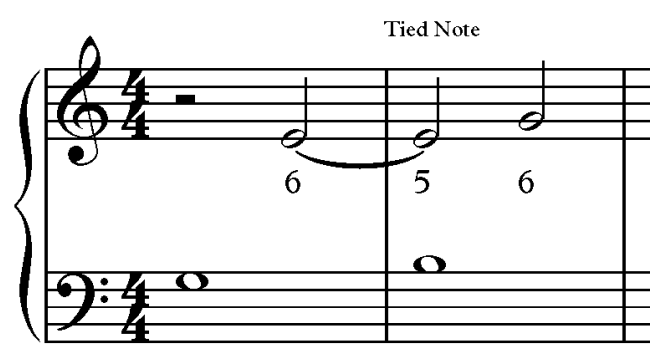

Notasi 5. Tied Note

e. Fifth species (florid counterpoint). Konsep pada florid counterpoint adalah menggunakan seluruh kaidah yang ada pada first species sampai dengan fourth species yang ditambah dengan penggunaan quaver note.

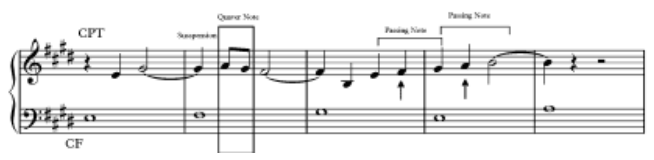

Notasi 6. Fifth Species

\section{KESIMPULAN}

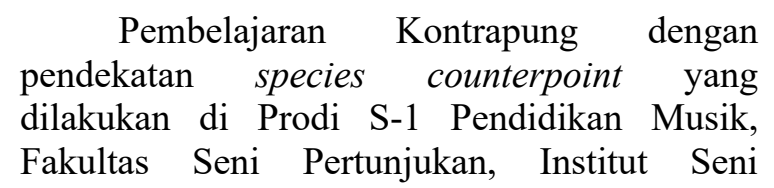

Indonesia Yogyakarta dipilih untuk digunakan agar dapat memberikan dasar pengetahuan yang kuat dalam memahami kaidah-kaidah pembuatan melodi Kontrapung. Penggunaan species counterpoint pada pembelajaran Kontrapung memberikan pemahaman secara kontinum dari kaidah dasar sampai dengan kaidah yang kompleks, sesuai dengan species yang dipelajari. Melalui pemahaman yang bertahap, species counterpoint memberikan kemudahan pada mahasiswa dalam menghafal dan memahami kaidah-kaidah pada pembuatan melodi Kontrapung (Jeppesen, 2013).

Pemahaman mahasiswa terhadap kaidahkaidah pembuatan melodi Kontrapung juga semakin diperkuat oleh latihan. Latihan diberikan pada bagian akhir pembahasan materi pada masing-masing species. Dengan mengerjakan latihan-latihan tersebut mahasiswa semakin memahami kaidah-kaidah pembuatan melodi Kontrapung. Selain mendapat pemahaman yang kuat, keterampilan dalam membuat melodi Kontrapung juga semakin meningkat. Hal ini diketahui dari nilai hasil belajar mahasiswa pada akhir semester yang menunjukkan adanya peningkatan nilai hasil belajar (84\% dari 38 mahasiswa mendapat nilai yang sangat baik dan baik, yaitu di antara nilai 75-100). Keterampilan dalam membuat melodi Kontrapung merupakan salah satu kompetensi dasar yang harus dicapai oleh mahasiswa yang menempuh perkuliahan musik, karena sebagian besar mata kuliah yang ada di Perguruan Tinggi Seni di Indonesia, khususnya Perguruan Tinggi yang memiliki Jurusan Musik adalah mata kuliah berdasarkan keterampilan (Indrawan, 2015). Dalam hal ini keterampian yang dimaksud adalah keterampilan dalam musik baik itu keterampilan dalam bermain musik ataupun keterampilan dalam mencipta musik.

Hasil pada penelitian ini menunjukkan bahwa pembelajaran Kontrapung dengan menggunakan species counterpoint memberikan manfaat yang besar pada mahasiswa, yaitu meningkatkan pemahaman mahasiswa terhadap kaidah-kaidah pembuatan melodi Kontrapung. Peningkatan pemahaman mahasiswa sekaligus menyatakan bahwa tujuan pembelajaran Kontrapung dapat tercapai. Meskipun demikian, peningkatan pemahaman terhadap melodi Kontrapung menurut mahasiswa dilakukan dengan menghafal setiap kaidah pada setiap species dan berlatih 
mengerjakan latihan-latihan yang dilakukan secara terus menerus.

\section{DAFTAR PUSTAKA}

Atmadja, B. T. (2009). Pengembangan Metode Pembelajaran Mata Kuliah Tari Surakarta Dasar. Resital: Jurnal Seni Pertunjukan (Journal of Performing Arts), 10(2).

Cholik, C. A. (2017). Pemanfaatan Teknologi Informasi Dan Komunikasi Untuk Meningkatkan Pendidikan Di Indonesia. Syntax Literate; Jurnal Ilmiah Indonesia, 2(6), 21-30.

Darsono, M. (2000). Belajar dan Pembelajaran. IKIP Semarang Press.

Djamarah, S. B., \& Zain, A. (2006). Strategi belajar mengajar. Jakarta: Rineka Cipta, 46.

Falahudin, I. (2014). Pemanfaatan media dalam pembelajaran. Jurnal Lingkar Widyaiswara, 1(4), 104-117.

Fux, J. J., \& Wollenberg, S. (1992). 'Gradus ad Parnassum'(1725): Concluding Chapters. Music Analysis, 11(2/3), 209-243.

Hanafy, M. S. (2014). Konsep Belajar dan Pembelajaran. Lentera Pendidikan: Jurnal Ilmu Tarbiyah Dan Keguruan, 17(1), 66-79.

Huang, C.-Z. A., Cooijmans, T., Roberts, A., Courville, A., \& Eck, D. (2019). Counterpoint by convolution. ArXiv Preprint ArXiv:1903.07227.

Indrawan, A. (2015). Adaptasi Konserto pada Ensambel Gitar sebagai Upaya Pengayaan Bahan Ajar Matakuliah Ensambel. Resital: Jurnal Seni Pertunjukan, 16(2).

Jeppesen, K. (2013). Counterpoint: the polyphonic vocal style of the sixteenth century. Courier Corporation.

Jeppesen, K., \& Haydon, G. (1935). On Counterpoint. The Musical Quarterly, 21(4), 401-407.

Komosinski, M., \& Szachewicz, P. (2015). Automatic species counterpoint composition by means of the dominance relation. Journal of Mathematics and Music, 9(1), 75-94.
Laitz, S. G. (2008). The Complete Musician (2nd ed.). New York: Oxford University Press, Inc.

Laksono, Y. T. (2019). Media Pembelajaran Interaktif Berbasis Software Fruity Loops Untuk Meningkatkan Pembelajaran Mata Kuliah Tata Suara. Virtuoso: Jurnal Pengkajian Dan Penciptaan Musik, 2(1), 41-46.

Mazzola, G., Park, J., \& Thalmann, F. (2011). The Contrapuntal Aspect. In Musical Creativity (pp. 73-84). Springer.

Nainggolan, O. T. P. (2018). Pembelajaran Kontrapung dengan Menggunakan Software Sibelius di Program Studi Pendidikan Musik Fakultas Seni Pertunjukan ISI Yogyakarta. PROMUSIKA: Jurnal Pengkajian, Penyajian, Dan Penciptaan Musik, 6(1), 22-30.

Norden, H. (1969). Fundamental counterpoint. Boston: Crescendo Pub. Co.

Pane, A., \& Dasopang, M. D. (2017). Belajar dan pembelajaran. Fitrah: Jurnal Kajian Ilmu-Ilmu Keislaman, 3(2), 333-352.

Ren, I. Y. (2016). Exploring the rules in species counterpoint. Proceedings of CSMC-16, Https://Csmc2016. Wordpress. Com/Proceedings.

Rothgeb, J. (1975). Strict counterpoint and tonal theory. Journal of Music Theory, 19(2), 260-284.

Sastrawan, K. B. (2016). Profesionalisme Guru Dalam Upaya Meningkatkan Mutu Pembelajaran. Jurnal Penjaminan Mutu, 2(2), 65-73.

Setyosari, P. (2017). Menciptakan pembelajaran yang efektif dan berkualitas. JINOTEP (Jurnal Inovasi Dan Teknologi Pembelajaran) Kajian Dan Riset Dalam Teknologi Pembelajaran, 1(1), 20-30.

Sugiyono, M. P. K. (2013). Kualitatif, dan Kombinasi (Mixed Methods). Bandung: Alfabeta.

York, F. L. (1907). Counterpoint Simplified: A Text-Book in Simple Strict Counterpoint. Boston: Oliver Ditson Company. 